\title{
The RAF family: an expanding network of post-transla- tional controls and protein-protein interactions
}

\author{
YURYEV ANTON, LAWRENCE P WENNOGLE \\ Novartis Pharmaceuticals Corporation, Summit, NJ, USA
}

\begin{abstract}
Protein kinase RAF is strategically located in the "Ras - MAP-kinase signal transduction pathway", a principle system which transmits signals from growth factor receptors to the nucleus, resulting in cell proliferation. Growth factor responses are mediated in part by activation of Ras, which in turn activates RAF to phosphorylate MEK, its downstream substrate. MEK activates MAPkinase to influence nuclear events. It is clear, however, that a network of signals other than those carried by Ras plays a role in RAF regulation. These orthogonal influences are mediated by: serine/threonine kinases, tyrosine kinases, and protein - protein interactions. As a further complication to the RAF network, three isoforms of RAF have been established which have divergent $\mathrm{N}$-terminal regulatory domains. Whereas these divergent regulatory domains implicate isoform-specific functions, no clear evidence or hypothesis for distinct functions for individual isoforms has been presented. Recently, "isoform-specific protein interactions" have been identified among numerous proteins interacting with RAF. These studies may serve to delineate independent functions for RAF isoforms.
\end{abstract}

\section{INTRODUCTION}

Since their discovery in the early 1980 's, RAF proteins ${ }^{1}$ have fascinated signal transduction experts and cell biologists. A number of reviews have dealt with var-

1.Correspondence author: Dr. Lawrence P. Wennogle, Novartis Pharmaceuticals Division,556 Morris Ave., LSB 3165 Summit NJ, 07901

Tele: 908-277-5697FAX: 908-277-4756 E-mail: Lawrence.Wennogle@pharma.novartis.com 
ious aspects of RAF including structure, function, Ras binding and activation[1-5]. The field has grown rapidly in the past two years, and during this period over 250 publications have appeared with the word "RAF" in the title. This review will focus on controls over RAF activity mediated by protein - protein interactions and by post-translational phosphorylation. The theme we will attempt to develop is that RAF plays a central role uniquely situated at a crossroads of signal transduction. An attempt to portray such an intricate and complex system will be made with the use of various analogies intended to provoke clarity and perspective.

RAF is a key intermediate of the growth factor -Ras- MAP kinase pathway (Fig 1) essential for cell proliferative responses. RAF isoforms are cytosolic proteins which serve as serine/threonine kinases. A variety of growth hormones, upon binding to their respective receptors, stimulate receptor dimerization and autophosphorylation at key tyrosine residues. Phosphotyrosine groups on the cytoplasmic domain of the receptor trigger formation of multi-component signal-transduction complexes which include members of Grb and SOS protein families. The complexes subsequently activate the small molecular weight GTPase Ras, by promoting the exchange of GDP for GTP. GTP-bound Ras activates RAF and initiates the subsequent phosphorylation/activation cascade through MEK and MAP-kinase. MAP-kinase phosphorylates nuclear transcription factors and thereby activates the expression of genes necessary for cell division.

\section{Historical perspective of the RAF family}

The identification of a truncated RAF in murine sarcoma virus 3611 as an oncogene[6] provided a key insight into the importance of this protein. More recently, antisense oligonucleotides specific to C-RAF isoform inhibited the proliferation of transformed cells[7, 8] and of growth factor stimulated cells[9], re-enforcing the influence of this system on cell growth. Genetic[10] and biochemical[11] studies place RAF in the Ras-MAP-kinase pathway between Ras and its downstream substrates - the MEK family of protein kinases.

The RAF family consists of at least three isoforms: A-RAF, B-RAF and C-RAF. Three isoforms of RAF were identified by cross hybridization[12] and enzymes from numerous species have been cloned including C. elegans, chicken, mouse, rat, baboon and human[13-15]. RAF-related pseudogenes exist in both human and baboon[12, 15-17]. The genes for RAF proteins are located on chromosomes: X, 7, and 3 (for A-, B-, and C-RAF, respectively)[12, 16, 17]. Genomic sequences are available which include information on promoter structure, introns, and exons (GenBank accession numbers: L24038, X65187, SEG- HUMRAF1).

\footnotetext{
${ }^{1}$ RAF isoforms will be referred to as A-, B, and C-RAF (also referred to in the literature as Raf1 or Mif-1) and sequence numbers, unless stated otherwise, refer to the human C-RAF sequence ( Genbank \#XO3484), historically, the most intensively studied isoform.
} 


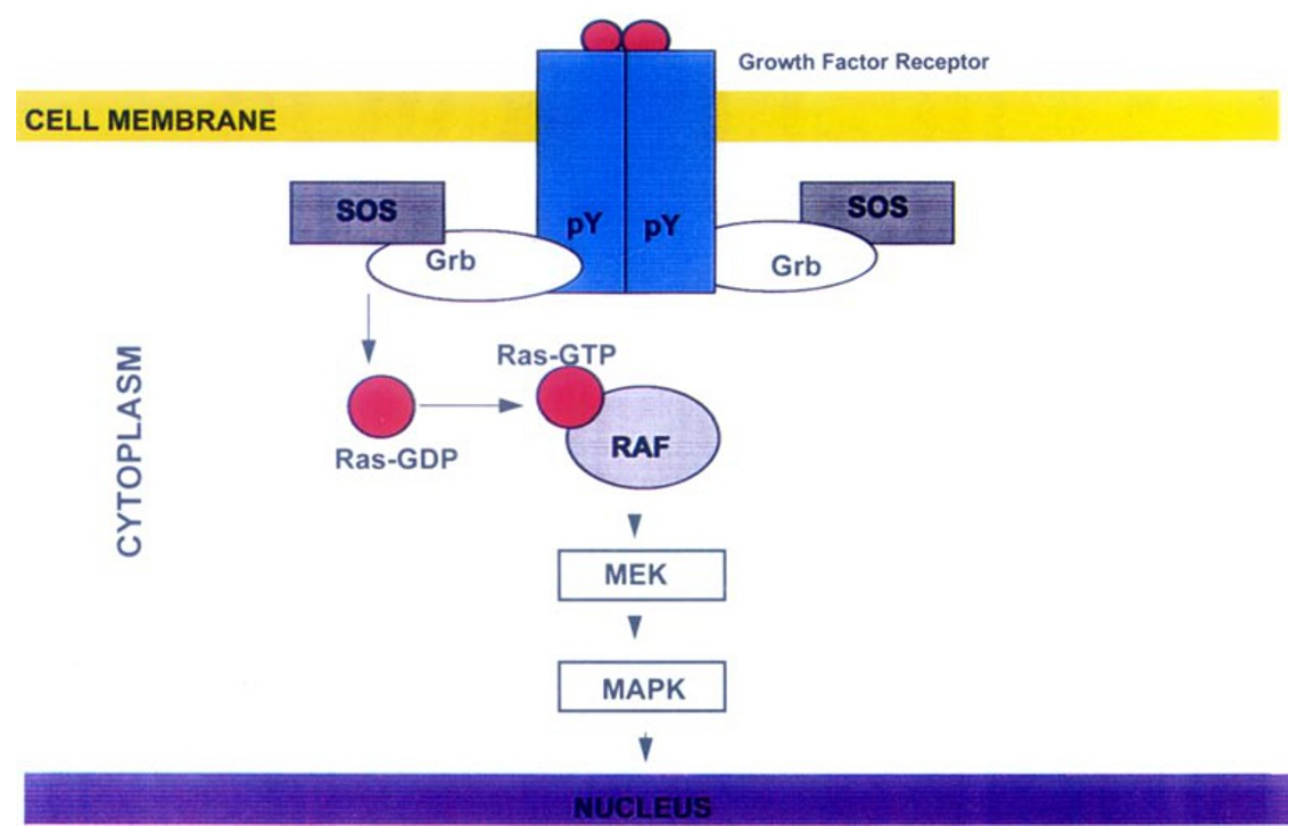

Fig 1. The schematic representation of Ras-RAF-MEK-MAPK signal transduction pathway. The signaling through the pathway is initiated by binding dimeric growth factor to corresponding growth factor receptor. Dimerization of the receptor leads to its autuphosphorylation on Tyr residues. Phosphotyrosine residues initiate the formation of the Grab-SOS signal transduction complex, which eventually lead to exchange of GDP to GTP in small molecular weight GTPase Ras. Ras-GTP molecule is capable of activating RAF, which triggers the cascade of consecutive phosphorylation/activation events and eventually lead to the phosphorylation and activation of the transcription factors. The proteins from each step of the pathway have multiple isoforms which precise functions are not understood.

An important issue is why has nature evolved three variations of this important kinase? The amino acid sequence of the three isoforms are aligned in Fig 2a. The C-terminal kinase domain is highly conserved among isoforms. The N-terminal regulatory domain is less conserved. Individual isoforms are highly conserved among different species from chicken to human. In fact, the conservation of a particular isoform between different species is higher than that between isoforms within a single species (Tab 1). This information clearly suggests that distinct roles for the individual RAF isoforms have evolved. Although information about RAF isoform cellular localization, which will be discussed below, is provocative, our understanding of the role of the individual isoforms remains unresolved. 
Reviewing the RAF network

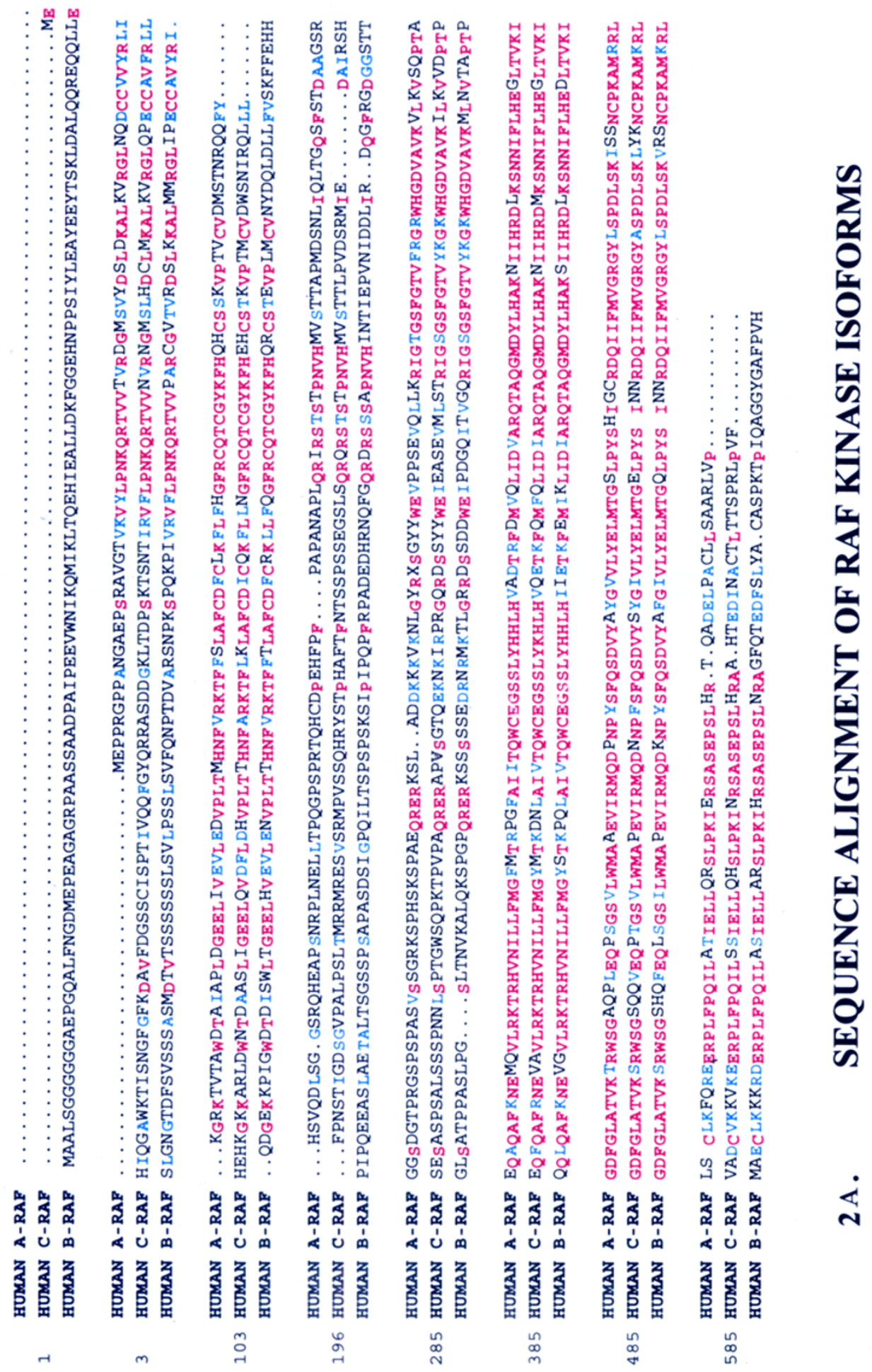




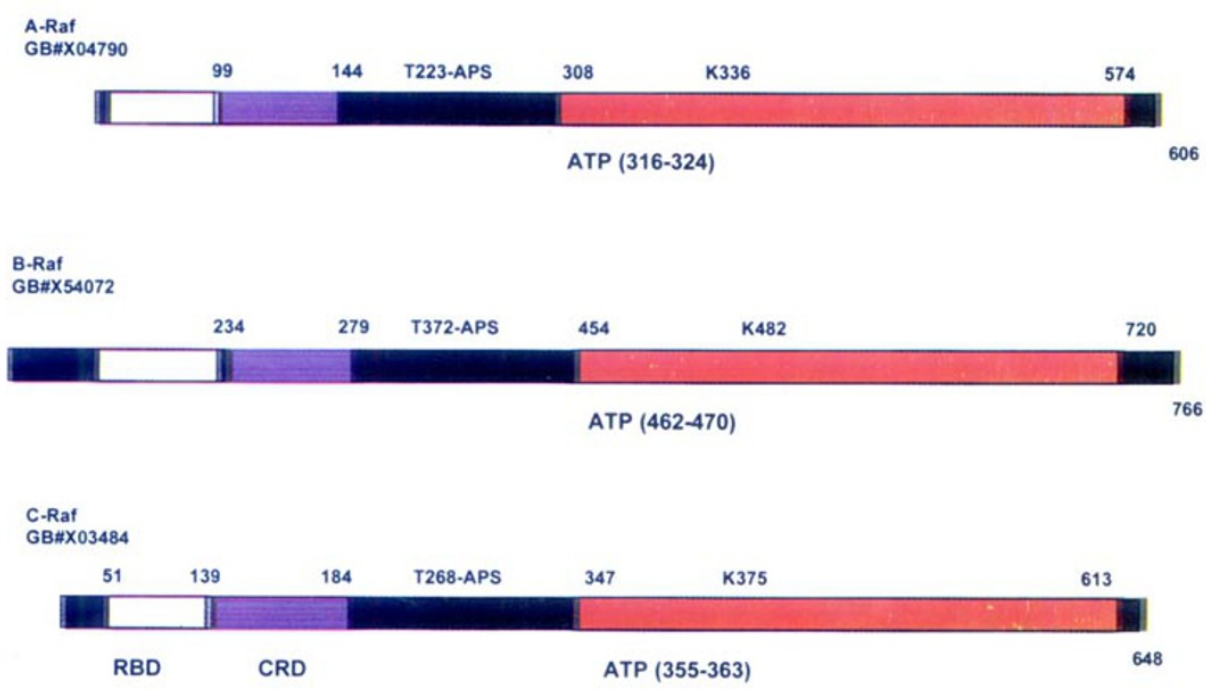

2 B. Three RAF-Kinase lsoforms

Fig 2. A. The sequence alignment of three RAF isoforms. Identical amino acids are in red, conserved substitutions are in blue, non-conserved amino acids are in black. Note the that highest number of identical amino acids are in the C-terminal catalytic region of RAF isoforms.

B. The schematic representation of three RAF isoforms. The Cysteine rich domain (CRD) is in purple, Ras binding domain (RBD) is in white, and serine/threonine protein kinase catalytic domain is in red. The numbers mark the beginning and the end of each domain in the isoform, and the total number of amino acids in each RAF isoform. Also are shown: Thr residue of the autophosphorylation site, ATP binding regions and the key catalytic Lys in the kinase domains.

A-RAF and C-RAF mRNAs have been detected in most tissues[29]. B-RAF isoform is predominantly expressed in adult mouse brain and testes. In addition, BRAF mRNA is expressed as four alternatively spliced messages in mouse brain[30]. Both A- and C-RAF can co-exist in a single cell. Rat smooth muscle A10 cells contain both A- and C-RAF as judged both by Western and Northern analysis[9]. Treatment of these cells with antisense to either isoform resulted in a non-additive decrease in cell proliferation[9].

All indications point to a dynamic regulation of RAF at the protein level as will be outlined below. There are no reports concerning the regulation of RAF activity at the level of protein expression or protein stability. C-RAF protein half-life in human coronary artery smooth muscle cells was reported to be $30 \mathrm{~h}$ [18]. C-RAF, 


\section{Reviewing the RAF network}

which is the most abundant RAF isoform, is a minor cellular component, estimated by labeling and immunoprecipitation experiments to represent $0.001 \%$ of the total cellular protein in CV1 kidney fibroblast cells[15].

Tab 1. Similarity of RAF Proteins

\begin{tabular}{llll}
\hline & \multicolumn{3}{c}{ Percent similarity (Identity) } \\
Three human isoforms & Full sequence & Regulatory domain & Kinase domain \\
\hline A-RAF/C-RAF & $75(62)$ & $64(48)$ & $88(77)$ \\
\hline A-RAF/B-RAF & $74(60)$ & $62(45)$ & $87(76)$ \\
\hline B-RAF/C-RAF & $75(59)$ & $62(41)$ & $91(80)$ \\
\hline Across Species & Full Sequence & Regulatory & Domain \\
\hline A-R AF Human / Rat & $97(95)$ & $96(92)$ & $98(99)$ \\
\hline B-R AF Human / Chicken & $97(95)$ & $95(91)$ & $100(100)$ \\
\hline C-RAF Human / Rat & $99(98)$ & $98(98)$ & $100(99)$ \\
\hline
\end{tabular}

Percent similarity accounts for conserved aminoacid substitutions within RAF sequence. Percent of identical aminoacids is given in brackets.

\section{Structure of R AF}

RAF can be pictured (Fig $2 \mathrm{~b}$ ) as a multi-domain protein containing a C-terminal kinase and a N-terminal regulatory domain containing several sub-domains. Analysis of the protein sequence ${ }^{2}$ reveals a consensus serine/threonine kinase domain (aa 347-613 in the C-RAF sequence), an ATP-binding motif (aa 355-363) and a cysteine-

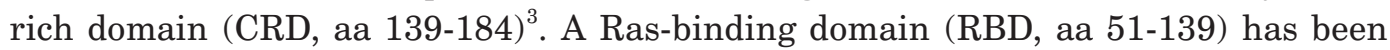
documented (Avruch and Morrison have reviewed the complex information on RasRAF interactions[3, 20]). High-resolution structure of the complex between RAF and Rap1a, a small molecular weight GTPase homologous to Ras, has been reported[21] (see also[22, 23]). Both the RBD and CRD participate in Ras binding.

\footnotetext{
${ }^{2}$ A useful Website for obtaining protein structural information of this type is the ExPASy site at the Geneva University Hospital and the University of Geneva h"ttp://expasy.hcuge.ch/www/expasytop.html". ". Domain searches can be done using p"fscan" at h"ttp://expasy.hcuge.ch/sprot/prosite.html". ${ }^{3}$ This cysteine-rich domain is different from cysteine-rich domains present in extracellular domains of receptor proteins (such as Prosite T "NFR NGFR" or I"ntegrin Beta"), or to the cysteine-rich domains involved in binding DNA which are also referred to as zinc fingers (such as Prosite G"ATA ZN FINGER")[19]. The p"fscan" program run on C-RAF defines aa 138-184 as a P"KC-C1 domain', aa 139-184 as a D" AG_PE_"BIND" binding domain, aa 152-184 as a Z" F-Ring finger
} 
Ras and Rap1a may compete for activation/inactivation of RAF by binding to the same binding site[24].

\section{The cysteine-rich domain}

The 45 amino acid (aa) region of C-RAF (aa 139-184) containing six cysteines and two histidines is referred to as a cysteine-rich domain (CRD) or a zinc finger[20] reviewed by Klug and Schwabe[19]. RAF CRD binds two zinc atoms[23]. This motif is similar to the diacylglycerol-binding $\mathrm{N}$-terminal domain of protein kinase $\mathrm{C}$ (PKC). However, unlike PKC, RAF does not bind phorbol esters[25] (See Footnote 3).

A growing body of evidence indicates that the RAF CRD is a major region for protein interaction and therefore regulation of RAF. Mutations of the CRD which affect RAF biological activities have been reported[20, 26]. The RAF CRD has been shown to bind phospholipids[27], a property that may be important during RAF translocation to the plasma membrane. The CRDs, analogous to the RAF CRD, are present in a variety of other kinases including KSR and 11 PKC isoforms[28], suggesting that the regulation of kinase activity through CRD is widespread. We will return to this aspect below.

\section{Kinase substrates}

The most established RAF substrates are the MEK family of protein kinases. MEK 1 kinase is phosphorylated in vitro by both C-RAF and B-RAF at Ser 218[31, 32]. MEK binds the catalytic domains of C-RAF and B-RAF, as demonstrated either with the yeast two-hybrid assay or with immunoprecipitation[33]. A-RAF was shown to bind and activate MEK1, but not MEK2[34]. I $\kappa$ B protein, a negative regulator of the NF- $\kappa \mathrm{B}$ transcription factor, is phosphorylated by C-RAF in vitro leading to an increase in NF- $\kappa$ B transcriptional activity[35]. A systematic study of RAF-kinase substrate requirements or a detailed enzyme kinetic analysis of this system has not been performed. This lack of information is due to the difficulty in the purification of active RAF and in part due to the fact that signal transduction components exist naturally as multiprotein complexes.

\section{Phosphorylation and post-translational control of RAF}

Phosphorylation of RAF represents a primary mechanism by which various lateral systems influence RAF activity. This area has been one of intense study. Both serine/threonine and tyrosine phosphorylation have been reported (Fig 3, Tab 2). Phosphorylation can result both in negative or positive effects on RAF catalytic activity. As detailed in the Tab 2, different methods have contributed to this information, some of which distinguish modifications that effect enzyme activity and others that pinpoint changes correlated with mitogen stimulation. 
Regulatory Domain

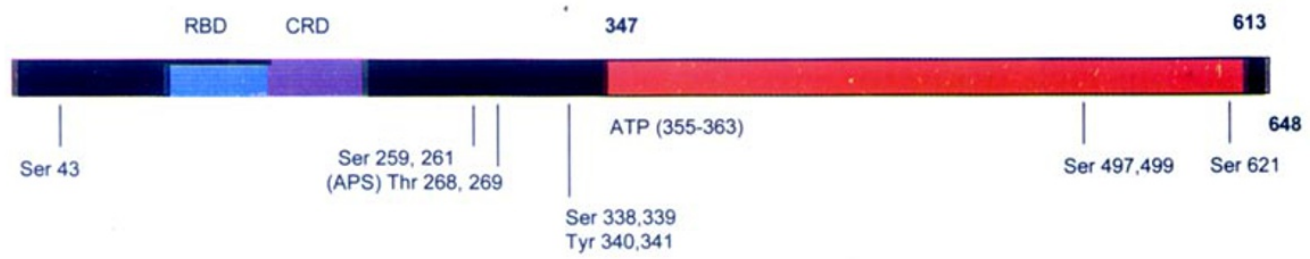

$\mathrm{CRD}=$ Cysteine-Rich domain (139-184) RBD=Ras-Binding Domain(55-131) APS=Autophosphorylation site

\section{C-Raf Domain Structure and Posphorylation Sites}

Fig 3. The schematic representation of the most studied C-RAF isoform with different phosphorylation sites. Table 2 shows the kinases and conditions which cause C-RAF phosphorylation.

Tab 2. List of known phosphorylation sites of RAF isoforms

\begin{tabular}{|c|c|c|c|c|c|}
\hline C-RAF site & $\begin{array}{l}\text {-SEQUENCE- } \\
\text { (Isoform ) }\end{array}$ & $\begin{array}{l}\text { Effect on } \\
\text { Activity }\end{array}$ & $\begin{array}{l}\text { in vitro } \\
\text { (Involved Kinase) }\end{array}$ & Cell type detected & Reference \\
\hline Ser 43 & $\begin{array}{l}-\mathrm{QRRASDD}- \\
(\mathrm{B}=\mathrm{C} \text { not } \mathrm{A})\end{array}$ & negative & PKA & quiescent $3 \mathrm{~T} 3, \mathrm{HFF}$ & $\begin{array}{l}{[36,37,} \\
39]\end{array}$ \\
\hline Ser 259,261 & $\begin{array}{l}- \text { QR ST STPN- } \\
(\mathrm{A}=\mathrm{B}=\mathrm{C})\end{array}$ & positive & $\begin{array}{l}\text { PKC a } \\
\text { PKA }\end{array}$ & $\begin{array}{l}\text { A431, PDGF-activated } \\
3 \mathrm{~T} 3, \mathrm{HFF},(\text { mitogen }+ \text { ) }\end{array}$ & $\begin{array}{l}{[37,39} \\
43,67]\end{array}$ \\
\hline Thr 268, 269 & $\begin{array}{l}-\mathrm{HMVSTTLPV}- \\
(\mathrm{A}=\mathrm{C} \operatorname{not} \mathrm{B})\end{array}$ & positive & $\begin{array}{l}\text { C-RAF autophos- } \\
\text { phorylation, CAPK }\end{array}$ & Sf9* & {$[39,68]$} \\
\hline Ser 338, 339 & $\begin{array}{l}- \text { RDSSYYWE- } \\
(\mathrm{A}=\mathrm{B}=\mathrm{C})\end{array}$ & positive & & COS-7 with ras-V12 & {$[42]$} \\
\hline Tyr 340,341 & $\begin{array}{l}\text {-RDSSYYWE- } \\
(\mathrm{A}=\mathrm{C} \text { not } \mathrm{B})\end{array}$ & positive & & Sf9 + v-src & {$[40]$} \\
\hline Ser 497, 499 & $\begin{array}{l}-\mathrm{RWSGSQQV-} \\
(\mathrm{B}=\mathrm{C} \operatorname{not} \mathrm{A})\end{array}$ & positive & $\mathrm{PKC} \alpha$ & quiescent $3 \mathrm{~T} 3$ & {$[43]$} \\
\hline Ser 621 & $\begin{array}{l}\text {-NRSASEP- } \\
(\mathrm{A}=\mathrm{B}=\mathrm{C})\end{array}$ & negative & PKA & Sf9* & {$[39,69]$} \\
\hline $\begin{array}{l}\{\mathrm{B}-\mathrm{RAF}\} \mathrm{Thr} \\
372\end{array}$ & -VHINTIE- & & $\begin{array}{l}\text { B-R AF autophos- } \\
\text { phory lation }\end{array}$ & & {$[70]$} \\
\hline
\end{tabular}

Sf9 is a baculovirus insect cell expression system. CAPK - ceramide-activated kinase 
Ser 43 can be phosphorylated in vitro by protein kinase A (PKA) or under conditions of cAMP increase, both of which represent a negative regulatory influence[3638]. Ser 43, Ser 259, and Ser 621 were found to be phosphorylated in insect Sf9 cells co-expressing activated PDGF receptors and C-RAF[39]. Tyr 340 and 341 were phosphorylated in insect cells when C-RAF was over-expressed together with the Src-family tyrosine kinases or with the JAK-2 kinase[40, 41]. Ser 338 and 339 were found to be phosphorylated in COS-7 cells when C-RAF was over-expressed with an oncogenic form of Ras[42]. The ability of PKC to phosphorylate RAF at Ser 259 and Ser 499 is well documented[43]. C-RAF autophosphorylates at Thr 268/269[39].

Many RAF isoforms have been cloned and expressed by the pioneering work from Ulf Rapp and colleagues. Importantly, expression of highly-active enzyme requires post-translational modification in the form of serine/threonine and tyrosine phosphorylations[39]. Co-expression of RAF with both a tyrosine kinase such as Src and with the Ras protein leads to maximal enzyme activity in a baculovirus expression system[44, 45]. Activation of RAF by phosphorylation allows for numerous and complex lateral influences on the RAF pathway. Like a river with numerous tributaries converging in a dynamic fashion, cell regulation through RAF is extensive and changeable.

\section{RAF protein-protein interactions}

RAF protein-protein interactions have been extensively studied by the yeast twohybrid screening method[46], by immunoprecipitation[15, 47], and by binding techniques[48, 49]. Tab 3 lists sixteen proteins shown to interact with RAF.

\section{RAF - Ras}

GTPases of the Ras family are the most well-studied proteins which interact with RAF. RAF has higher affinity for GTP-Ras over GDP- Ras[27]. Over-expression of Ras activates RAF, and over-expression of the N-terminal domain of RAF blocks the Ras transforming ability[50]. Several Ras-related small molecular weight GTPases can interact with C-RAF including: Ha-Ras[46, 51], Rap-1A[52], R-Ras [53], Rhe$\mathrm{b}[54]$.

Ras is normally farnesylated and palmitoylated in vivo at C-terminal cysteine residues[55, 56]. These modifications result in the trans-localization of Ras to the membrane. A proposed function for Ras is to target RAF to the membrane via this mechanism. Mutant RAF proteins, encoding C-terminal farnesylation signals to mimic the effect of Ras, were shown to be isoprenylated. These constructs were preferentially membrane localized and resulted in cell transformation.

\section{RAF - 14-3-3 protein interaction}

RAF has been shown to interact with 14-3-3 proteins[57]. These 14-3-3 proteins 
Reviewing the RAF network

Tab 3. List of Published Proteins Interacting with RAF

\begin{tabular}{|c|c|c|c|c|}
\hline Protein name & $\begin{array}{l}\text { Swiss Prot/ } \\
\text { Gen Bank } \\
\text { accession number }\end{array}$ & $\begin{array}{l}\mathrm{RAF} \text { isoform } \\
\text { interaction domain }\end{array}$ & Method & Reference \\
\hline $\begin{array}{l}\text { Ha-Ras, R-ras, } \\
\text { Rap1A, Rheb }\end{array}$ & $\begin{array}{l}\mathrm{P} 01112, \mathrm{P} 10301, \\
\mathrm{P} 10113, \mathrm{~S} 68419\end{array}$ & $\begin{array}{l}\text { C-RAF RBD domain, 55-131 } \\
\text { C-RAF CRD, 139-185 }\end{array}$ & in vitro, two-hybrid & {$[27,54]$} \\
\hline $14-3-3 \beta, \zeta, \theta, \mathrm{h}$ & $\begin{array}{l}\text { P31946, P29312, } \\
\text { P27348, Q04917 }\end{array}$ & $\begin{array}{l}\text { C-RAF CRD, 139-185 } \\
\text { B-RAF N-termnus, 1-443 }\end{array}$ & $\begin{array}{l}\text { IP, two-hybrid, } \\
\text { in vitro }\end{array}$ & {$[59,71,72]$} \\
\hline $\begin{array}{l}\beta \text {-subunit of trimeric } \\
\text { G-protein }\end{array}$ & & C-RAF & two-hybrid & {$[73]$} \\
\hline BAG 1 & Q99933 & $\begin{array}{l}\text { C-RAF kinase domain, } \\
303-648\end{array}$ & $\begin{array}{l}\text { two-hybrid, in vitro, } \\
\text { IP }\end{array}$ & {$[74]$} \\
\hline $\mathrm{Bcl} 2$ & P10415 & $\begin{array}{l}\text { C-RAF kinase domain, } \\
303-648\end{array}$ & two-hybrid, in vitro & {$[75]$} \\
\hline Fyn & P06241 & & & {$[76]$} \\
\hline $\begin{array}{l}\beta \text { subunit of Casein } \\
\text { kinase } 2\end{array}$ & $\mathrm{P} 13862$ & $\begin{array}{l}\text { A-R AF kinase domain, } \\
255-587\end{array}$ & two-hybrid & {$[64,65]$} \\
\hline MEK1, MEK 2 & Q13233, P36507 & $\begin{array}{l}\text { C-R AF kinase domain, } \\
303-648 \\
\text { B-RAF kinase domain, } \\
333-767\end{array}$ & two-hybrid, IP & {$[71,77]$} \\
\hline $\mathrm{c}-\mathrm{Myc}$ & P01106 & C-RAF & in vitro & {$[78]$} \\
\hline $\mathrm{IkB}$ & P25963 & $\begin{array}{l}\text { C-RAF kinase domain, } \\
303-648\end{array}$ & in vitro, two-hybrid & {$[35]$} \\
\hline $\begin{array}{l}\text { Heat Shock Proteins } \\
\text { hsp90+ p50 }\end{array}$ & P08238 & C-Raf & IP & {$[15,79,80]$} \\
\hline
\end{tabular}

IP = immunoprecipitation, Two-hybrid = the yeast Two- Hybrid analysis, "in vitro" refers to various other biochemical techniques such as "Far Western Analysis" or Affinity Chromotography methods.

are abundant cytosolic proteins which appear to act as co-factors to a variety of cytosolic proteins (reviewed in[58]). The interaction of RAF with 14-3-3 proteins is complex. The binding of a 14-3-3 protein to RAF is influenced by RAF phosphory- 
lation on Ser259[3, 59, 60]. This serine is contained within a -RxSxSpxP- sequence which has been shown to be the 14-3-3 binding motif[60]. Conversely, phosphorylation of 14-3-3 protein by casein kinase I abolish 14-3-3 binding to RAF[61]. Over-expression of 14-3-3 protein activates signaling through RAF[62, 63]. However, recent publications argue that 14-3-3 proteins inhibit RAF activity in vivo, because a mutated RAF, that is unable to bind 14-3-3 protein, has enhanced transforming activity[26]. Reconciliation of these diverse observations and of the multiple contact regions is an ongoing effort.

\section{Other RAF - protein interactions}

Six proteins have been described to interact with the RAF catalytic domain (Tab 3 ), of the which only I $\kappa \mathrm{B}$ are phosphorylated by RAF. In the two-hybrid assay, $\beta$ subunit of casein kinase II binds to the C-terminal domain of A-RAF but not $\mathrm{C}-\mathrm{RAF}[64,65]$. The functional significance of this interaction is not understood.

We have performed extensive yeast two-hybrid screens with both A-RAF and $\mathrm{C}-\mathrm{RAF}$ in search of isoform-specific protein interactions. These studies identified 20 RAF-interacting proteins using the poorly conserved $\mathrm{N}$-terminal regulatory domain of RAF as the bait (aa 1-314 of A-RAF and aa 1-353 of C-RAF)[28]. Several novel RAF-interacting proteins were identified and sequenced. Among these is a novel protein kinase referred to as hA38, a kinase which binds non-selectively to all three RAF isoforms. In addition, several isoform-specific RAF binding partners were identified. These include two mitochondrial membrane transport proteins which bind specifically to A-RAF. Subsequently, A-RAF was localized inside purified rat liver mitochondria by Western analysis[66]. This finding has led to the hypothesis that A$\mathrm{RAF}$ isoform is selectively located in rat liver mitochondria where it may coordinate mitochondrial replication, energy production, or potentially apoptosis[66].

All 20 proteins we identified as binding to RAF N-terminal domain interacted with the RAF CRD. The fact that the CRD was sufficient for their interaction suggested that the CRD is a principle site for RAF protein-protein interactions. Closer inspection of the amino acid sequence of the CRD region from the three RAF isoforms (Fig 2a) reveals that this sequence is highly conserved. Of the 45 residues only 12 amino acids are different among the isoforms, however, seven of these changes result in changes of charge. Because we have determined that the CRD is sufficient to interact with all of the RAF binding partners[28], we infer that these specific residues play a key role in specifying isoform-specific interactions. The numerous proteins reported to interact with RAF suggest a busy and dynamic intersection with competition from multiple directions.

\section{Cellular functions of the RAF network}

An expanding list of receptor signals has been shown to activate RAF (Tab 4). Although a general list of this type probably contains unestablished "cause and ef- 


\section{Reviewing the R AF network}

fect" relationships, it attests to the broad influence of the RAF network. Included in this coverage are receptors for growth factors, for cytokines and for seven-transmembrane spanning receptors. The variety of signals which impinge upon RAF reiterates the fundamental importance of this protein to signal transduction. Because the decision for a cell to divide is a fundamentally profound one, a sophisticated integration of information and therefore control occurs in the cytosol at the level of RAF, prior to signal transmission into the nucleus.

Tab 4. Examples of cellular responses

\begin{tabular}{|c|c|c|}
\hline Input or receptor & Cell type & Reference \\
\hline Gamma irradiation & breast cancer cells & {$[81]$} \\
\hline PACAP-like neuropeptide & Drosophila & {$[82]$} \\
\hline 12-O-tetradecanoylphorbol-13-acetate (TPA) & Madin-Darby canine kidney cells,3T3 & {$[83,84]$} \\
\hline Interleukin -5 & eosinophils & {$[85]$} \\
\hline Insulin-like growth factor I & Balb/c, rat cardiac myocytes & {$[86,87]$} \\
\hline $\mathrm{Ca}^{2+}$ mobilizer thapsigargin & $\mathrm{Balb} / \mathrm{c}$ & {$[88]$} \\
\hline Trimeric G-Protein & HEK 293 cells & {$[89]$} \\
\hline Bone morphogenetic protein 4 & Xenopus oocytes & {$[90]$} \\
\hline Bile acid secretion by tauroursodeoxycholaterat & liver & {$[91]$} \\
\hline Angiotensin II and PDGF & smooth muscle & {$[92]$} \\
\hline Fibroblast-derived growth factor & rat hippocampalneurons & {$[93]$} \\
\hline Integrin mediated cell attachment & & {$[94]$} \\
\hline Prostaglandin F2- $a$ & arat uterine & {$[95]$} \\
\hline$\beta$-interferon,oncostatin $\mathrm{M}$ & HeLa cells & {$[96]$} \\
\hline Lactosylceramide & smooth muscle cell proliferation & {$[97]$} \\
\hline Prolactin & mammary cells & {$[98]$} \\
\hline a l-adrenergic receptor agonist & rat ventricular myocytes & {$[99]$} \\
\hline Bombesin and neuromedin B & Rat-1 cells & {$[100]$} \\
\hline ICAM-1 & B cell lymphoma line & {$[101]$} \\
\hline Gonadotropin-releasing hormone & a T3-1 cell line & {$[102]$} \\
\hline $\mathrm{G}-\mathrm{CSF}$ & myeloid NFS-60 cells & {$[103]$} \\
\hline TGF $\beta 1$ & rat hepatic stellate cells & {$[104]$} \\
\hline Osmolarity & C6 glioma cells & [105] \\
\hline Erythropoietin and inositolphosphate-glycan & erythroid progenitor cells & {$[106]$} \\
\hline
\end{tabular}

IP = immunoprecipitation, Two-hybrid = the yeast Two- Hybrid analysis, "in vitro" refers to various other biochemical techniques such as "Far Western Analysis" or Affinity Chromotography methods. 


\section{Summary and conclusions}

This review has focused on the expanding number of complexities to the RAF network, particularly at the level of protein - protein interactions and at RAF phosphorylation by lateral systems. In view of these complexities, the importance of RAF in integrating information from numerous systems is obvious. More effort is needed to fully define the spectrum of proteins which interact directly with RAF and to delineate the unique functions of RAF isoforms.

\section{ACKNOWLEDGEMENT}

We thank Dr. Matthew Toth for valuable comments on the manuscript.

\section{REFERENCES}

[1] Daum G, Eisenmann-Tappe I, Fries HW, Troppmair J, Rapp UR. The ins and outs of Raf kinases. Trends Biochem Sci 1994; 19:474-80.

[2] Avruch J, Zhang XF, Kyriakis JM. Raf meets Ras: completing the framework of a signal transduction pathway. Trends Biochem Sci 1994; 19:279-83.

[3] Morrison DK, Cutler RE. The complexity of Raf-1 regulation. Curr Opin Cell Biol 1997; 9:174-9.

[4] Morrison DK. Mechanisms regulating Raf-1 activity in signal transduction pathways. Mol Reprod Dev 1995; 42:507-14.

[5] Magnuson NS, Beck T, Vahidi H, Hahn H, Smola U, Rapp UR. The Raf-1 serine/threonine protein kinase. Semin Cancer Biol 1994; 5:247-53.

[6] Mark GE, Rapp UR. Primary structure of v-raf: relatedness to the src family of oncogenes. Science 1984; 224:285-9.

[7] Monia BP, Sasmor H, Johnston JF, et al. Sequence-specific antitumor activity of a phosphorothioate oligodeoxyribonucleotide targeted to human C-raf kinase supports an antisense mechanism of action in vivo. Proc Natl Acad Sci USA 1996; 93:15481-4.

[8] Monia BP. First- and second-generation antisense oligonucleotide inhibitors targeted against human c-raf kinase. Ciba Found Symp 1997; 209:107-19.

[9] Cioffi CL, Garay M, Johnson JF, et al. Selective Inhibition of A-Raf and C-Raf mRNA Expression by Antisense Oligodeoxynucleotides in Rat Vascular Smooth Muscle Cells: Role of A-Raf and C-Raf in Serum-Induced Proliferation. Molecular Pharmacology 1997; 51:383-9.

[10] Karim FD, Chang HC, Therrien M, Wassarman DA, Laverty T, Rubin GM. A screen for genes that function downstream of Rasl during Drosophila eye development. Genetics 1996; 143:31529.

[11] Sternberg PW, Golden A, Han M. Role of a raf proto-oncogene during Caenorhabditis elegans vulval development. Philos Trans R Soc Lond B Biol Sci 1993; 340:259-65.

[12] Bonner TI, Kerby SB, Sutrave P, Gunnell MA, Mark G, Rapp UR. Structure and biological activity of human homologs of the raf/mil oncogene. Mol Cell Biol 1985; 5:1400-7.

[13] Mark GE, Pfeifer A, Mann DL, Harris CC, Berman R, Pert CB. raf protooncogene expression in neural and immune tissues. Adv Biochem Psychopharmacol 1988; 44:45-55.

[14] Han M, Golden A, Han Y, Sternberg, PW. C. elegans lin-45 raf gene participates in let-60 ras-stimulated vulval differentiation. Nature 1993; 363:133-40.

[15] Mandiyan S, Schumacher C, Cioffi C, et al. Molecular and cellular characterization of baboon C-Raf as a target for antiproliferative effects of antisense oligonucleotides. Antisense and nucleic acid drug development 1997; 7:539-48. 


\section{Reviewing the RAF network}

[16] Sithanandam G, Druck T, Cannizzaro LA, Leuzzi G, Huebner K, Rapp UR. B-raf and a B-raf pseudogene are located on 7q in man. Oncogene 1992; 7:795-9.

[17] Lee JE, Beck TW, Brennscheidt U, DeGennaro LJ, Rapp UR. The complete sequence and promoter activity of the human A-raf-1 gene (ARAF1). Genomics 1994; 20:43-55.

[18] Schumacher C, Cioffi CL, Sharif H, Haston W, Monia BP, Wennogle LP. Exposure of Human Vascular Smooth Muscle Cells to Raf-1 Antisense Oligodeoxynucleotides: Cellular Responses and Pharmacodynamic Implications. Mol Pharmacol 1998; 53:97-104.

[19] Klug A, W.R.S. Zinc fingers. EASEB 1995; 9:597-604.

[20] Luo Z, Diaz B, Marshall MS, Avruch J. An intact Raf zinc finger is required for optimal binding to processed Ras and for ras-dependent Raf activation in situ. Mol Cell Biol 1997; 17:46-53.

[21] Nassar N, Horn G, Herrmann C, Scherer A, McCormick F, Wittinghofer A. The 2.2 A crystal structure of the Ras-binding domain of the serine/threonine kinase c-Rafl in complex with RaplA and a GTP analogue. Nature 1995; 375:554-60.

[22] Emerson SD, Madison VS, Palermo RE, et al. Solution structure of the Ras-binding domain of c-Raf-1 and identification of its Ras interaction surface. Biochemistry 1995; 34:6911-8.

[23] Mott HR, Carpenter JW, Zhong S, Ghosh S, Bell RM, Campbell SL. The solution structure of the Raf-1 cysteine-rich domain: a novel ras and phospholipid binding site. Proc Natl Acad Sci U S A 1996; 93:8312-7.

[24] Vossler MR, Yao H, York RD, Pan MG, Rim CS, Stork PJ. cAMP activates MAP kinase and Elk-1 through a B-Raf- and Rapl-dependent pathway. Cell 1997; 89:73-82.

[25] Kazanietz MG, Bustelo XR, Barbacid M, et al. Zinc finger domains and phorbol ester pharmacophore. Analysis of binding to mutated form of protein kinase $\mathrm{C}$ zeta and the vav and c-raf proto-oncogene products. J Biol Chem 1994; 269:11590-4.

[26] Clark GJ, Drugan JK, Rossman KL, et al. 14-3-3 zeta negatively regulates raf-1 activity by interactions with the Raf-1 cysteine-rich domain. J Biol Chem 1997; 272:20990-3.

[27] Ghosh S, Xie WQ, Quest AF, Mabrouk GM, Strum JC, Bell RM. The cysteine-rich region of raf-1 kinase contains zinc, translocates to liposomes, and is adjacent to a segment that binds GTP-ras. J Biol Chem 1994; 269:10000-7.

[28] Yuryev A, Ono M, Goff SA, L.P.W. Characterization of Raf kinase isoform specific interactions by two-hybrid screen analysis. in preparation 1998;

[29] Storm SM, Cleveland JL, Rapp UR. Expression of raf family proto-oncogenes in normal mouse tissues. Oncogene 1990; 5:345-51.

[30] Barnier JV, Papin C, Eychene A, Lecoq O, Calothy G. The mouse B-raf gene encodes multiple protein isoforms with tissue-specific expression. J Biol Chem 1995; 270:23381-9.

[31] Zheng CF, Guan KL. Activation of MEK family kinases requires phosphorylation of two conserved Ser/Thr residues. Embo J 1994; 13:1123-31.

[32] Papin C, Eychene A, Brunet A, et al. B-Raf protein isoforms interact with and phosphorylate Mek-1 on serine residues 218 and 222. Oncogene 1995; 10:1647-51.

[33] Van Aelst L, Barr M, Marcus S, Polverino A, Wigler M. Complex formation between RAS and RAF and other protein kinases. Proc Natl Acad Sci USA 1993; 90:6213-7.

[34] Wu X, Noh SJ, Zhou G, Dixon JE, Guan KL. Selective activation of MEK1 but not MEK2 by A-Raf from epidermal growth factor-stimulated Hela cells. J Biol Chem 1996; 271:3265-71.

[35] Li S, Sedivy JM. Raf-1 protein kinase activates the NF-kappa B transcription factor by dissociating the cytoplasmic NF-kappa B-I kappa B complex. Proc Natl Acad Sci USA 1993; 90:9247-51.

[36] Wu J, Dent P, Jelinek T, Wolfman A, Weber MJ, Sturgill TW. Inhibition of the EGF-activated MAP kinase signaling pathway by adenosine 3', 5'-monophosphate [see comments]. Science 1993; 262:1065-9.

[37] Schramm K, Niehof M, Radziwill G, Rommel C, Moelling K. Phosphorylation of c-Raf-1 by protein kinase A interferes with activation. Biochem Biophys Res Commun 1994; 201:740-7. 
[38] Cook SJ, McCormick F. Inhibition by cAMP of Ras-dependent activation of Raf [see comments]. Science 1993; 262:1069-72.

[39] Morrison DK, Heidecker G, Rapp UR, Copeland TD. Identification of the major phosphorylation sites of the Raf-1 kinase. J Biol Chem 1993; 268:17309-16.

[40] Fabian JR, Daar IO, Morrison DK. Critical tyrosine residues regulate the enzymatic and biological activity of Raf-1 kinase. Mol Cell Biol 1993; 13:7170-9.

[41] Xia K, Mukhopadhyay NK, Inhorn RC, et al. The cytokine-activated tyrosine kinase JAK2 activates Raf-1 in a p21ras- dependent manner. Proc Natl Acad Sci USA 1996; 93:11681-6.

[42] Diaz B, Barnard D, Filson A, MacDonald S, King A, Marshall M. Phosphorylation of Raf-1 serine 338-serine 339 is an essential regulatory event for Ras-dependent activation and biological signaling. Mol Cell Biol 1997; 17:4509-16.

[43] Kolch W, Heidecker G, Kochs G, et al. Protein kinase C alpha activates RAF-1 by direct phosphorylation. Nature 1993; 364:249-52.

[44] Williams NG, Roberts TM, Li P. Both p21ras and pp60v-src are required, but neither alone is sufficient, to activate the Raf-1 kinase. Proc Natl Acad Sci USA 1992; 89:2922-6.

[45] Kikuchi A, Demo SD, Ye ZH, Chen YW, Williams LT. ralGds family members interact with the effector loop of ras p21. Mol Cell Biol 1994; 14:7483-91.

[46] Zhang XF, Settleman J, Kyriakis JM, et al. Normal and oncogenic p21ras proteins bind to the amino-terminal regulatory domain of c-Raf-1. Nature 1993; 364:308-13.

[47] Wartmann M, Davis RJ. The native structure of the activated Raf protein kinase is a membranebound multi-subunit complex. J Biol Chem, 1994; 269:6695-701.

[48] Warne PH, Viciana PR, Downward J. Direct interaction of Ras and the amino-terminal region of Raf-1 in vitro. Nature 1993; 364:352-5.

[49] Chuang E, Barnard D, Hettich L, Zhang XF, Avruch J, Marshall MS. Critical binding and regulatory interactions between Ras and Raf occur through a small, stable N-terminal domain of Raf and specific Ras effector residues. Mol Cell Biol 1994; 14:5318-25.

[50] Kolch W, Heidecker G, Lloyd P, Rapp UR. Raf-1 protein kinase is required for growth of induced NIH/3T3 cells. Nature 1991 1991; 349:426-8.

[51] Brtva TR, Drugan JK, Ghosh S, et al. Two distinct Raf domains mediate interaction with Ras. J Biol Chem 1995; 270:9809-12.

[52] Herrmann C, Horn G, Spaargaren M, Wittinghofer A. Differential interaction of the ras family GTP-binding proteins H-Ras, RaplA, and R-Ras with the putative effector molecules Raf kinase and Ral-guanine nucleotide exchange factor. J Biol Chem 1996; 271:6794-800.

[53] Rey I, Taylor-Harris P, van Erp H, Hall A. R-ras interacts with rasGAP, neurofibromin and c-raf but does not regulate cell growth or differentiation. Oncogene 1994; 9:685-692.

[54] Yee WM, Worley PF. Rheb interacts with Raf-1 kinase and may function to integrate growth factor- and protein kinase A-dependent signals. Mol Cell Biol 1997; 17:921-33.

[55] Omer CA, Gibbs JB. Protein prenylation in eukaryotic microorganisms: genetics, biology and biochemistry. Mol Microbiol 1994; 11:219-25.

[56] Casey PJ, Seabra MC. Protein prenyltransferases. J Biol Chem 1996; 271:5289-92.

[57] Fu H, Xia K, Pallas DC, et al. Interaction of the protein kinase Raf-1 with 14-3-3 proteins [see comments]. Science 1994; 266:126-9.

[58] Aitken A, Howell S, Jones D, Madrazo J, Patel Y. 14-3-3 alpha and delta are the phosphorylated forms of raf-activating 14-3-3 beta and zeta. In vivo stoichiometric phosphorylation in brain at a Ser-Pro-Glu-Lys MOTIF. J Biol Chem 1995; 270:5706-9.

[59] Rommel C, Radziwill G, Lovric J, et al. Activated Ras displaces 14-3-3 protein from the amino terminus of c-Raf- 1 . Oncogene 1996; 12:609-19.

[60] Muslin AJ, Tanner JW, Allen PM, Shaw AS. Interaction of 14-3-3 with signaling proteins is mediated by the recognition of phosphoserine. Cell 1996; 84:889-97.

[61] Dubois T, Rommel C, Howell S, et al. 14-3-3 is phosphorylated by casein kinase I on residue 233. Phosphorylation at this site in vivo regulates Raf/14-3-3 interaction. J Biol Chem 1997; 


\section{Reviewing the RAF network}

\section{2:28882-8.}

[62] Shimizu K, Kuroda S, Yamamori B, et al. Synergistic activation by Ras and 14-3-3 protein of a mitogen-activated protein kinase kinase kinase named Ras-dependent extracellular signalregulated kinase kinase stimulator. J Biol Chem 1994; 269:22917-20.

[63] Li S, Janosch P, Tanji M, et al. Regulation of Raf-1 kinase activity by the 14-3-3 family of proteins. EMBO J 1995; 14:685-96.

[64] Boldyreff B, Issinger OG. A-Raf kinase is a new interacting partner of protein kinase CK2 beta subunit. FEBS Lett 1997; 403:197-9.

[65] Hagemann C, Kalmes A, Wixler V, Wixler L, Schuster T, Rapp UR. The regulatory subunit of protein kinase CK2 is a specific A-Raf activator. FEBS Lett 1997; 403:200-2.

[66] Yuryev A, Ono M, Goff SA, L.P.W. Localization of A-Raf and related signal transduction components in mitochondria. in preparation 1998;

[67] Beimling P, Niehof M, Radziwill G, Moelling K. The aminoterminus of c-Raf-1 binds a protein kinase phosphorylating Ser259. Biochem Biophys Res Commun 1994; 204:841-8.

[68] Yao B, Zhang Y, Delikat S, Mathias S, Basu S, Kolesnick R. Phosphorylation of Raf by ceramideactivated protein kinase. Nature 1995; 378:307-10.

[69] Mischak H, Seitz T, Janosch P, et al. Negative regulation of Raf-1 by phosphorylation of serine 621. Mol Cell Biol 1996; 16:5409-18.

[70] Stephens RM, Sithanandam G, Copeland TD, Kaplan DR, Rapp UR, Morrison DK. 95-kilodalton B-Raf serine/threonine kinase: identification of the protein and its major autophosphorylation site. Mol Cell Biol 1992; 12:3733-42.

[71] Papin C, Denouel A, Calothy G, Eychene A. Identification of signalling proteins interacting with B-Raf in the yeast two-hybrid system. Oncogene 1996; 12:2213-21.

[72] Freed E, Symons M, Macdonald SG, McCormick F, Ruggieri R. Binding of 14-3-3 proteins to the protein kinase Raf and effects on its activation. Science 1994; 265:1713-6.

[73] Pumiglia KM, LeVine H, Haske T, Habib T, Jove R, Decker SJ. A direct interaction between G-protein beta gamma subunits and the Raf-1 protein kinase. J Biol Chem 1995; 270:14251-4.

[74] Wang HG, Takayama S, Rapp UR, Reed JC. Bcl-2 interacting protein, BAG-l, binds to and activates the kinase Raf-1. Proc Natl Acad Sci USA 1996; 93:7063-8.

[75] Wang HG, Rapp UR, Reed JC. Bcl-2 targets the protein kinase Raf-1 to mitochondria [see comments]. Cell 1996; 87:629-38.

[76] Cleghon V, Morrison DK. Raf-1 interacts with Fyn and Src in a non-phosphotyrosine-dependent manner. J Biol Chem 1994; 269:17749-55.

[77] Aelst L, Barr M, Marcus S, Polverino A, Wigler M. Complex formation between RAS and RAF and other protein kinases. Proc Natl Acad Sci USA 1993; 90:6213-7.

[78] Alexandrov I, Shlyakhova L, Vartanian A, Zajac-Kaye M, Alexandrova N. c-Raf kinase binds to N-terminal domain of c-Myc. FEBS Lett 1997; 414:465-70.

[79] Schulte TW, Blagosklonny MV, Ingui C, Neckers L. Disruption of the Raf-l-Hsp90 molecular complex results in destabilization of Raf-1 and loss of Raf-l-Ras association. J Biol Chem 1995; 270:24585-8.

[80] Schulte TW, Blagosklonny MV, Romanova L, et al. Destabilization of Raf-1 by geldanamycin leads to disruption of the Raf-l-MEK-mitogen-activated protein kinase signalling pathway. Mol Cell Biol 1996; 16:5839-45.

[81] Suy S, Anderson WB, Dent P, Chang E, Kasid U. Association of Grb2 with Sos and Ras with Raf-1 upon gamma irradiation of breast cancer cells. Oncogene 1997; 15:53-61.

[82] Zhong Y. Genetic dissection of signal transduction mechanisms underlying PACAP-like neuropeptide transmission in Drosophila: synergy of cAMP and Ras/Raf pathways. Ann N Y Acad Sci 1996; 26:67-79.

[83] Ueda Y, Hirai S, Osada S, Suzuki A, Mizuno K, Ohno S. Protein kinase C activates the MEKERK pathway in a manner independent of Ras and dependent on Raf. J Biol Chem 1996; 271:23512-9. 
[84] Ghosh S, Strum JC, Sciorra VA, Daniel L, Bell RM. Raf-1 kinase possesses distinct binding domains for phosphatidylserine and phosphatidic acid. Phosphatidic acid regulates the translocation of Raf-1 in 12-O-tetradecanoylphorbol-13-acetate-stimulated Madin-Darby canine kidney cells. J Biol Chem 1996; 271:8472-80.

[85] Alam R, Pazdrak K, Stafford S, Forsythe P. The interleukin-5/receptor interaction activates Lyn and Jak2 tyrosine kinases and propagates signals via the Ras-Raf-1-MAP kinase and the Jak- STAT pathways in eosinophils. Int Arch Allergy Immunol 1995; 107:226-7.

[86] Chao TS, Foster DA, Rapp UR, Rosner MR. Differential Raf requirement for activation of mitogen-activated protein kinase by growth factors, phorbol esters, and calcium. J Biol Chem 1994; 269:7337-41.

[87] Foncea R, Andersson M, Ketterman A, et al. Insulin-like growth factor-I rapidly activates multiple signal transduction pathways in cultured rat cardiac myocytes. J Biol Chem 1997; 272:19115-24.

[88] Chao TS, Abe M, Hershenson MB, Gomes I, Rosner MR. Src tyrosine kinase mediates stimulation of Raf-1 and mitogen-activated protein kinase by the tumor promoter thapsigargin. Cancer Res 1997; 57:3168-73.

[89] Ito A, Satoh T, Kaziro Y, Itoh H. G protein beta gamma subunit activates Ras, Raf, and MAP kinase in HEK 293 cells. FEBS Lett 1995; 368:183-7.

[90] Xu RH, Dong Z, Maeno M, et al. Involvement of Ras/Raf/AP-1 in BMP-4 signaling during Xenopus embryonic development. Proc Natl Acad Sci USA 1996; 93:834-8.

[91] Schliess F, Kurz AK, vom Dahl S, Haussinger D. Mitogen-activated protein kinases mediate the stimulation of bile acid secretion by tauroursodeoxycholate in rat liver. Gastroenterology 1997; 113:1306-14.

[92] Marrero MB, Schieffer B, Li B, Sun J, Harp JB, Ling BN. Role of Janus kinase/signal transducer and activator of transcription and mitogen-activated protein kinase cascades in angiotensin IIand platelet-derived growth factor-induced vascular smooth muscle cell proliferation. J Biol Chem 1997; 272:24684-90.

[93] Kuo WL, Abe M, Rhee J, et al. Raf, but not MEK or ERK, is sufficient for differentiation of hippocampal neuronal cells. Mol Cell Biol 1996; 16:1458-70.

[94] King WG, Mattaliano MD, Chan TO, Tsichlis PN, Brugge JS. Phosphatidylinositol 3-kinase is required for integrin-stimulated $\mathrm{AKT}$ and Raf-1/mitogen-activated protein kinase pathway activation. Mol Cell Biol 1997; 17:4406-18.

[95] Ohmichi M, Koike K, Kimura A, et al. Role of mitogen-activated protein kinase pathway in prostaglandin F2alpha-induced rat puerperal uterine contraction. Endocrinology 1997; 138:310311.

[96] Stancato LF, Sakatsume M, David M, et al. Beta interferon and oncostatin M activate Raf-1 and mitogen-activated protein kinase through a JAKl-dependent pathway. Mol Cell Biol 1997; 17:3833-40.

[97] Bhunia AK, Han H, Snowden A, Chatterjee S. Redox-regulated signaling by lactosylceramide in the proliferation of human aortic smooth muscle cells. J Biol Chem 1997; 272:15642-9.

[98] Das R, Vonderhaar BK. Tamoxifen inhibits prolactin signal transduction in ER - NOG-8 mammary epithelial cells. Cancer Lett 1997; 116:41-6.

[99] Ramirez MT, Sah VP, Zhao XL, Hunter JJ, Chien KR, Brown JH. The MEKK-JNK pathway is stimulated by alphal-adrenergic receptor and ras activation and is associated with in vitro and in vivo cardiac hypertrophy. J Biol Chem 1997; 272:14057-61.

[100] Charlesworth A, Rozengurt E. Bombesin and neuromedin B stimulate the activation of p42(mapk) and $\mathrm{p} 74(\mathrm{raf}-1)$ via a protein kinase C-independent pathway in Rat-1 cells. Oncogene 1997; 14:2323-9.

[101] Holland J, Owens T. Signaling through intercellular adhesion molecule 1 (ICAM-1) in a B cell lymphoma line. The activation of Lyn tyrosine kinase and the mitogen-activated protein kinase pathway. J Biol Chem 1997; 272:9108-12. 


\section{Reviewing the RAF network}

[102] Reiss N, Llevi LN, Shacham S, Harris D, Seger R, Naor Z. Mechanism of mitogen-activated protein kinase activation by gonadotropin-releasing hormone in the pituitary of alphaT3-1 cell line: differential roles of calcium and protein kinase C. Endocrinology 1997; 138:1673-82.

[103] Csar XF, Ward AC, Hoffmann BW, Guy GG, Hamilton JA. cAmp suppresses p21ras and Raf-1 responses but not the Erk-1 response to granulocyte-colony-stimulating factor: possible Raf-1independent activation of Erk-1. Biochem J 1997; 322:79-87.

[104] Reimann T, Hempel U, Krautwald S, et al. Transforming growth factor-beta1 induces activation of Ras, Raf-1, MEK and MAPK in rat hepatic stellate cells. FEBS Lett 1997; 403:57-60.

[105] Sinning R, Schliess F, Kubitz R, Haussinger D. Osmosignalling in C6 glioma cells. FEBS Lett 1997; 400:163-7.

[106] Devemy E, Billat C, Haye B. Activation of Raf-1 and mitogen-activated protein kinases by erythropoietin and inositolphosphate-glycan in normal erythroid progenitor cells: involvement of protein kinase C. Cell Signal 1997; 9:41-6.

Received March-1 1-1998. Revised April-20-1998. Accepted April-28-1998. 